Predrag Mijatović
Vladan Pavlović $^{2}$
Ljubiša Milačić $^{3}$
JEL:E22;M21;M40;L83;M21;C14;C61;D61

DOI: $10.5937 /$ industrija43-7548

UDC:658.14:[796.332:061.2(497.11)"2009/2012"

336.13

Case research

\title{
Effect of investment on financial and sports results ${ }^{4}$
}

\author{
Article history: \\ Received: 14 January 2015 \\ Sent for revision: 27 January 2015 \\ Received in revised form: 3 March 2015 \\ Accepted: 30 May 2015 \\ Available online: 2 July 2015
}

\begin{abstract}
This study investigated the correlation between investment, financial results and sport results achieved and to evaluate the relative efficiency of Serbian football clubs. In this regard, two postulations were examined: firstly, investments in football clubs produce better sports results; secondly, investments in football clubs result in a stronger financial position. A correlation analysis and Data Envelopment Analysis (CCR model) were applied. Thirteen football clubs were included in the analysis, which represents eighty per cent of the Serbian Football League First Division Clubs. The study was conducted in the period 2009-2011that includes football seasons 2009-2010, 2010-2011 and 2011-2012. A strong positive correlation between investment and sport results was found only for the top football clubs, while the econometric regression did not show any correlation. The findings also show that there is no relation between investment and net income. The analysis of technical efficiency confirmed these findings, which revealed that the best football clubs are usually the farthest away from the efficiency frontier.
\end{abstract}

Key words: Football, Technical efficiency, Data Envelopment Analysis (DEA), Sports performances, Financial performance, Serbia.

\section{Efekat investiranja na finansijski i sportski rezultat}

Apstrakt: Rad ima za cilj da istraži vezu između ulaganja, finansijskog rezultata i sportskog rezultata i da oceni relativnu efikasnost srpskih fudbalskih

\footnotetext{
${ }^{1}$ Wellness Saruna, Belgrade, Serbia, serbos@live.com

${ }^{2}$ University of Priština, Faculty of Economics, Serbia

${ }^{3}$ University of Priština, Faculty of Agriculture, Serbia

${ }^{4}$ This paper is the result of research on the Project No. 179001 which is funded by the Ministry of Education, Science, and Technological Development of the Republic of Serbia
} 
klubova. U tom smislu, dva postulata su ispitana: prvo, ulaganja u fudbalske klubove dovodi do boljeg sportskog rezultata; drugo, ulaganje u fudbalske klubove dovodi do jače finansijske pozicije. U radu su primenjene korelaciona analiza $i$ analiza obavijanja podataka (CCR model). Trinaest fudbalskih klubova je obuhvaćeno analizom koji predstavljaju osamdeset procenata klubova koji se takmiče u 1. Srpskoj fudbalskoj Ligi. Analiza je rađena za period 2009-2011 koji uključuje sezone 2009-2010, 2010-2011 i 2011-2012. Visoka pozitivna korelacija između ulaganja i sportskog rezultata je nađena samo kod klubova na vrhu tabele, dok ekonometrijska analiza nije pokazala značajnu korelaciju. Rezultati takođe pokazuju da ne postoji veza između ulaganja i neto prihoda. Analiza tehničke efikasnosti potvrdila je ove zaključke i otkriva da su najbolji fudbalski klubovi obično $i$ najudaljeniji od granice efikasnosti.

Ključne reči: Fudbal; tehnička efikasnost; analiza obavijanja podataka (DEA); sportske performanse; finansijske performanse; Srbija.

\section{Introduction}

Sports clubs and leagues, as basic organisational units of sports, pay greater attention to both economic and financial aspects. Earlier, sport results were the only aim of football clubs while football clubs mainly focused on entertaining and educating the members of the community. Today, in relation to organisational structure, professional football clubs are no different from other firms in the private sector; therefore, the financial aspects are becoming increasingly important in football management. The majority of both European and Serbian professional football clubs have a legal form of a company (additional information in: Pavlović et al., 2013). Thus, it is not surprising that when Chip Moore and John Allen were asked "Is working for a professional sports team different from working in Corporate America?" the former answered, "Can't make a comparison; business is business", and the latter (Controller, Cincinnati Reds) answered "In reality, it's not that much different. There are still the same situations" (Gette, 1996). However, in comparison to other institutions, the sports industry has one significant feature. Contrary to economic theory, competition in the football industry is more profitable than monopoly, and, in literature, the above-mentioned occurrence is known as the Louis-Schmeling paradox (Morrow, 1999).

In theory, today, football clubs certainly focus on both financial and sports success. However, there is still no unified perspective on a primary measure of success in football. Some authors believe that sports success is the most important achievement, while they consider financial success as a means of providing the sustainability and achievements of a club. Other authors give equal importance to sports and financial achievements. Unlike the above- 
mentioned, the third group of authors emphasise on club value maximization. The fourth group of authors emphasise that "the ultimate aim of a club is survival" (Espitia-Escuer \& Garcia-Cerebrian, 2010:1). Samagaio et al. (2009) state that sports managers seek to maximise sports performance, at the same time making sure that the club does not have an operating loss, even when the club is owned by a group of investors. It is not surprising that the market value of a club is predominantly determined by sports success, and value maximisation represents the main objective of investors. It is important to highlight here that negative goodwill is not rare in the football industry.

Despite different attitudes, a demand for the synergy of sports and financial results is evident, and has always been more or less present in all clubs. Accordingly, both sports and financial success represent the two main factors in assessing a football club's efficiency (Barros \& Leach, 2006). Barros et al. (2010) underline the importance of the optimisation of sports and financial results, and the increased importance of the evaluation of efficiency, primarily due to the fact that there is a direct relationship between sports results of a club and its financial position in the long term.

As pointed out by Vrooman (2007:309), the challenge for economic theory is to find a dynamic balance between "love and money necessary" to analytically grasp the passionate and pragmatic complexities of the beautiful game.

\section{Literature review}

Over the past few years, researchers have become more interested in the correlation between sports and financial performances of football clubs. Barajas et al. (2005:17) "found that there is a non-linear relationship, with an explanation degree of $55.12 \%$, between budget (expected income) of Spanish football clubs and sports performance". Pinnuck and Potter (2004) reported that a positive result influences match attendance, and consequently, it has an influence on financial results. Samagaio et al. (2009) investigated the correlation among sporting, financial and stock market performances of English football clubs. The results showed that there was a strong linear correlation between financial and sports performances. Szymanski and Smith (1997) stated that there was a linear correlation between profit and sports performances. According to the research, title holders generate revenue, midtable clubs have large losses, while relegation fodders (bottom of the league) have small losses.

The Data Envelopment Analysis (DEA) method is widely used for measuring efficiency of both profit and non-profit organisations (Cvijanovic et al., 2010; Cvijanovic et al., 2012). The DEA method has also been used in numerous studies to measure the efficiency of football clubs management, technical and 
tactical efficiency of players and teams, financial and sporting efficiency of clubs, financial and sporting efficiency of leagues, etc. The research conducted by Bosca et al. (2009) is interesting. They used the DEA method to measure offensive and defensive efficiency of Spanish and Italian football clubs, as well as tactical differences of clubs when playing at home and when playing away. Another interesting study was conducted by Picazo-Tadeo and Gonzales-Gomez (2010). The DEA method was used to analyse the influence of international games on the efficiency of Spanish football clubs at competition level (when playing nationally and internationally).

The DEA method is commonly used in the sports industry. This method has proven to be one of the basic methods for the measurement of the efficiency of football clubs in both Europe and USA, and over the last few years its application has become more frequently used in other parts of the world too. For example, Lee (2009) used the DEA method to evaluate management efficiency of Korean football clubs. Barros et al. (2010) implemented the method to evaluate the efficiency of Brazilian first league football clubs, while Soleimani-Damaneh et al. (2011) utilised the DEA method to evaluate sports and financial performance of Iranian football clubs. The DEA method is also widely used for the evaluation of the efficiency of other sports, such as basketball (Radovanović et al., 2013) and the Tour de France cycling teams (Rogge et al., 2013).

The DEA method involves the usage of pre-selected input variables, which represent used resources and output variables, which represent business results. Depending on the purpose of the research, the availability of information and authors' preferences, diverse parameters for input and output variables of a model are used. Input variables that are the most commonly used in the DEA method for the evaluation of the efficiency of football clubs, are operating expenditures, players' salaries and coaches' salaries, while the most commonly used output values are net income, operating incomes, number of points awarded, winning percentage, rankings, average viewers per game, population size of the club's city, etc. Sports performance is presented as a mixture of variables. Some authors use the variables by combining results achieved in national and international competitions, also by the estimation of club value as a brand. Haas et al. (2004) used players' and coaches' salaries as input variables, and output was measured by the points awarded, total revenues and average stadium utilisation. Jardin (2009) used total salary and population size of the club's city for input variables; and number of points at the end of the season and the total income for the output variables. Barros and Leach (2006) obtained their output variables by combining three indicators: number of the points awarded, average attendance and revenues. Number of players, players' salary and spending, net assets and stadium costs were used as the input variables in this research. 
The results of the research usually suggest that expenditures should be reduced, mainly transfer costs and wage expenditures. For example, Haas et al. (2004) conclude that the most promising way for inefficient teams to reach efficiency is to cut wage expenditures. The continuous increase of players' salary spending and players' transfer jeopardises the football industry. In this regard, UEFA provides explicit actions by their regulations (UEFA, 2012).

One of the problems that researchers often face during the evaluation of the efficiency of football clubs is the absence of financial reports of some clubs, and unpublished or inaccurate important information, such as financial reports that are incorrect or with inadequate footnotes. The problems of data unavailability and relevance have been identified by the majority of researchers (Barajas, 2009; Samagaio et al., 2009; Barros et al., 2010). The relative availability of data in some studies represents a key factor in the selection of input and output parameters (Barros et al., 2010). The problem of unavailability or inaccuracy of published information is present even in the most developed European countries. Therefore, in his article, for example, Barajas (2009) stated that Spanish football clubs face not only a lack of financial transparency, but also delays in presenting financial statements.

\section{Purpose of the study}

The first part of the research aims to determine the correlation among football clubs' investments, sports results, investments of football clubs and financial results, and is followed by the evaluation of technical efficiency of these clubs.

\section{Materials and Methods}

\subsection{Club selection}

Thirteen football clubs of Serbian first league are included for analysis, namely: F.C. Partizan, F.C. Crvena Zvezda, F.C. Vojvodina, Y.F.C. Beograd, F.C. Rad, F.C. Spartak Subotica, F.C. Sloboda Point, F.C. Javor, F.C. Borac, F.C. Smederevo, F.C. Jagodina, F.C. Hajduk and F.C. Metalac. For the purpose of this analysis, the football clubs were categorised into three groups. The first group consists of title holder clubs, the second group consists of midtable clubs, and the third group consists of relegation fodders. The analysis was conducted for the period 2009-2011, namely the football season 2009/10 and 2011/12. 
Mijatović P. et al.: Effect of investment on financial and sports results

\subsection{Ethical issues}

No intrusive measures were applicable in this study. Furthermore, institutions in Serbia do not as yet have the practice or facility of providing or confirming ethical clearance numbers.

\subsection{Football industry}

Unlike other industries, the most important resources in the football industry are human resources (Pavlović, Ljumović \& Knežević, 2014). Consequently, salaries represent the highest expenditure. Related to human resources, transfer fees are the next highest costs (Pavlović, Milačić \& Ljumović, 2014). However, transfer fees apply only to football players who were transferred from the clubs where they still had contractual obligations, but these expenditures do not apply to all football players. The extent to which transfer fees will be applicable depends mainly on the policy of the football club. If a club recruits players from its resources, like juniors, or renews contracts with players or engages players from other clubs whose contract has expired, transfer fees will be minimal. Another feature of the football industry is reflected in the fact that smaller transfer fees result in higher salaries. Finally, unlike other industries, the most important resources (players) are often sold before their contract ends, which results in recurrent gain or loss from the sale. Unlike European football clubs, Serbian ones still give transfer shares to the former football club of a player, managers, agencies, investment funds, and even to players themselves, hence clubs are sometimes left with only one half of gained profit.

\subsection{Collection of data}

The data were taken from annual financial reports published on the web page of the Serbian Business Registers Agency and the web page of the Football Association of Serbia. Unavailability of financial results represented the main reason why some clubs were not included in the three-year limited analysis.

\subsection{Analysis of data}

Based on the nature of the football industry, the conclusion of this analysis is that the investment income ratio and ROA (Return On Assets) are less useful than the reciprocal value of the cost/income ratio. The cost/income ratio is the ratio between operating expenses and operating income, which is most commonly used in the financial sector. However, for the purpose of this analysis, net income was used instead of operating income, for two reasons. Firstly, football clubs can present profit or loss from the sale of players as 
extraordinary items and secondly, financial expenditures mostly occur from paying off transfer fees, which are not inevitable, but mainly arise as a consequence of a club's policy.

The limitation of this research lies in the selection of methods for the evaluation of their efficiency. Particularly, the Serbian Jelen super league consists of clubs whose financial assets are not comparable. The DEA method, which is the most commonly used method for the evaluation of the success of football clubs, was used for the evaluation of the efficiency of the Serbian First League in this research. Specifically, the CCR (Charnes, Cooper, Rhodes) method of one input and two outputs has been applied.

Total expenditures were used as input variables, while total revenues and overvalued position on table were used as outputs. Output 1 (total revenues) represents the financial indicator while Output 2 (overvalued position) represents the indicator of sport success. The position in the table represents the classification of a club based on results achieved in a championship, while an overvalued position in the table is achieved by the inverted ranking of the position. The geometric series are used to represent the position in the table. Accordingly, output 1 represents the financial result, and output represents sports result. The analysis was conducted using both input and output models. In the input model, the aim was to minimise total expenditures, while at the same time equal output values (revenues and points) remain. The output-oriented model seeks to maximise outputs for the same output value. Both cases have a common position of efficiency frontier, which was expressed by value 1 , while inefficient units were oriented differently depending on a model.

The correlation between clubs was the same in both models; the only difference was the direction of relatively inefficient projection of clubs. The diagrams will show both input and output projections of the results. Clubs which are close to the efficiency frontier make the enveloped line, while relatively inefficient clubs become wrapped down if a model is input/output oriented. Hypothetical units can be created for all inefficient units Par', CZv', Voj', OFK', Rad', Spa', Slo', Jav', BČ', Sme', Jag', Haj' and Met' on the efficiency frontier, which is made as a linear combination of inputs and outputs of two efficiency frontier units with hypothetical units in the middle. For inefficient units whose hypothetical units do not pass between two efficiency frontier units, the hypothetical unit $Q$ of a virtually non-existed clubs is added in order to determine the hypothetical units. The Efficiency Index can be calculated as a ratio between the radial distance of an observed DMU (Decision Making Unit) of coordinate beginning, and the radial distance of its reference point of coordinate beginning (O Par'/OPar, OCrZ'/OCrZ, OVoj'/OVoj, OOFK'/OOFK ORad'/ORad, OSpa'/OSpa, Oslo'/Oslo, 
Mijatović $P$. et al.: Effect of investment on financial and sports results

OJav'/OJav, OBČ'/OBČ, OSme'/OSme, OJag'/OJag, OHaj'/OHaj, and OMet'/OMet).

\section{Results and discussion}

\subsection{Effects of investment on sports results}

The dispersion diagram (Figure 1) clearly shows a strong positive correlation between investment and sports results of hopefuls for the title (clubs that take the first four places). The correlation coefficient for this club in the given period is 0.93045 .

Figure 1. Effects of investment on sports results for best ranked clubs

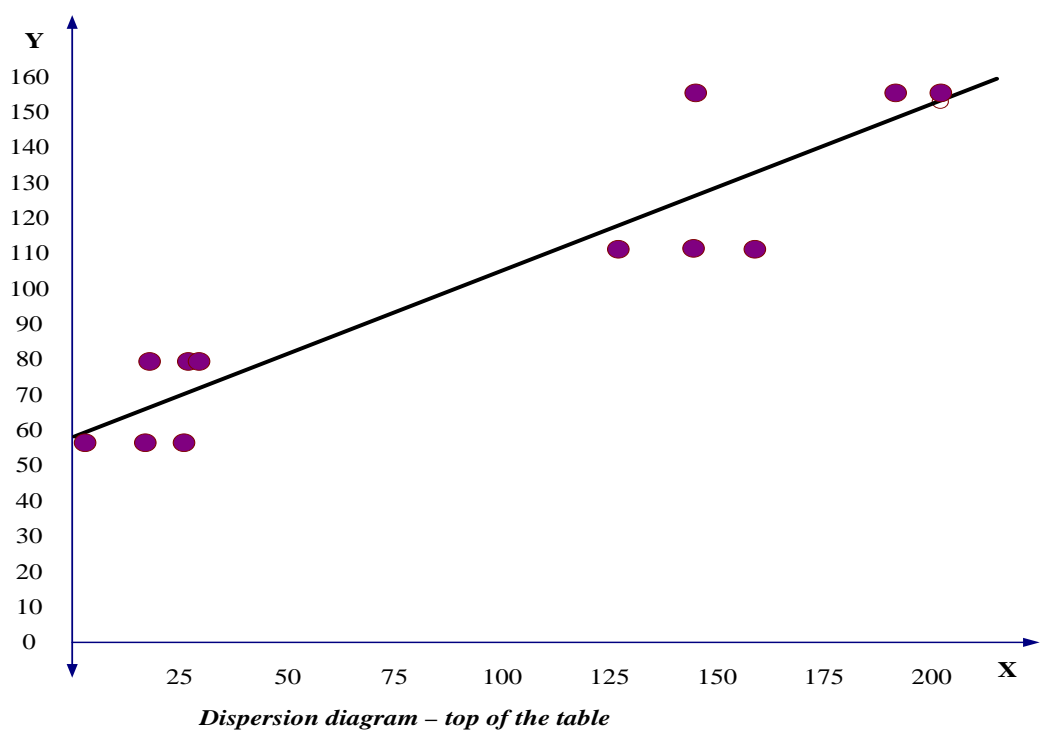

The dispersion diagram (Figure 2) clearly shows that there is no econometric regression correlation dependence between investment and sports results of the clubs at the middle of the table. 
Mijatović $P$. et al.: Effect of investment on financial and sports results

Figure 2. Effects of investment on sports results for middle of table clubs

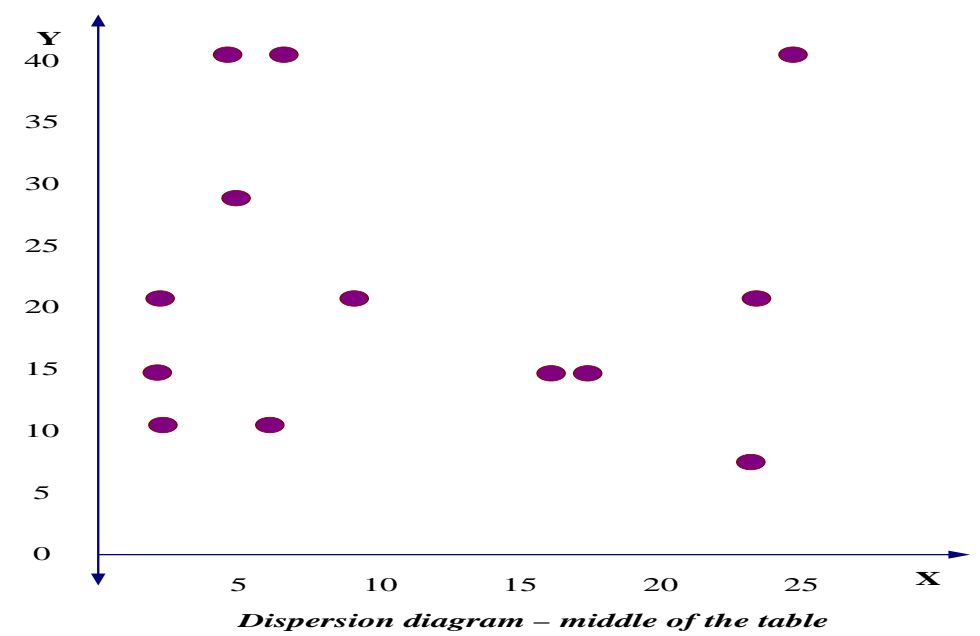

The dispersion diagram of Figure 3 clearly illustrates that there is no econometric regression correlation dependence between investment and sports results of the clubs at the bottom of the table.

Figure 3. Effects of investment on sports results for bottom of table clubs

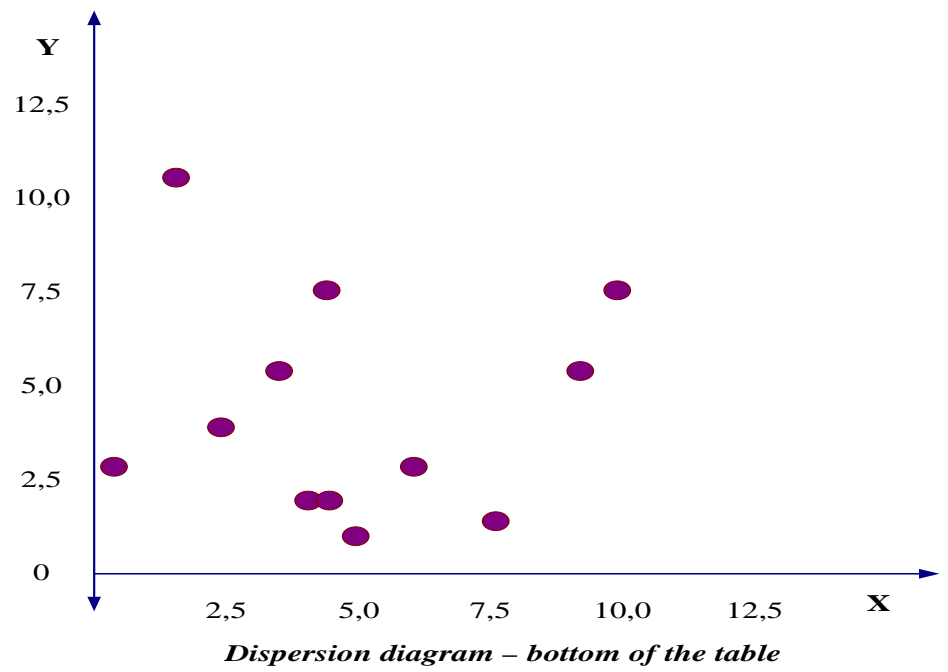


Mijatović P. et al.: Effect of investment on financial and sports results

\subsection{Effects of investment on net income}

There is no econometric regression correlation between investment and net income for the clubs at the top of the table as can be seen in the dispersion diagram of Figure 4.

Figure 4. Effects of investment on net income of best ranked clubs

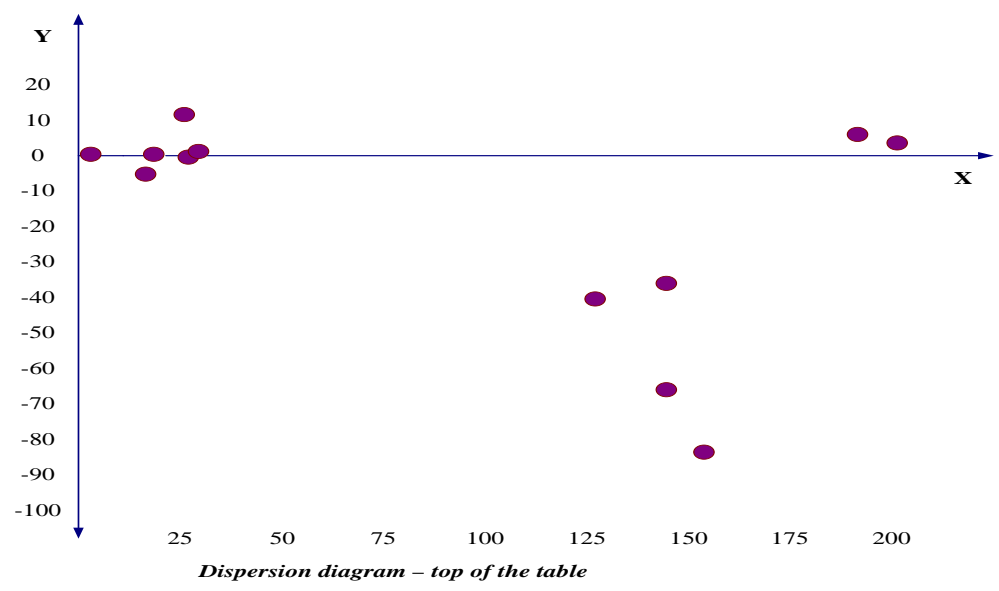

The dispersion diagram (Figure 5) noticeably shows that there is no econometric regression correlation between investment and net income for the clubs at the middle of the table.

Figure 5. Effects of investment on net income for clubs in middle of table.

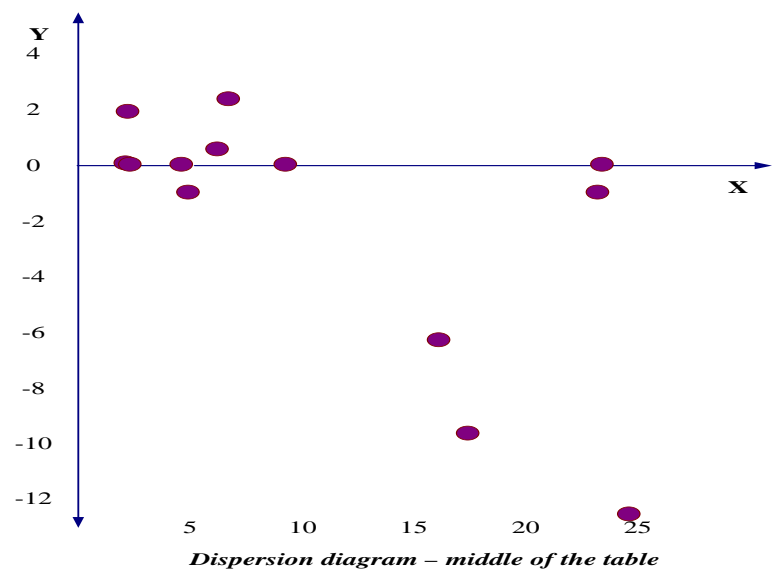


Mijatović $P$. et al.: Effect of investment on financial and sports results

According to results plotted in Figure 6, there is no econometric regression correlation between investment and net income for the clubs at the bottom of the table.

Figure 6. Effects of investment on net income of clubs at bottom of table.

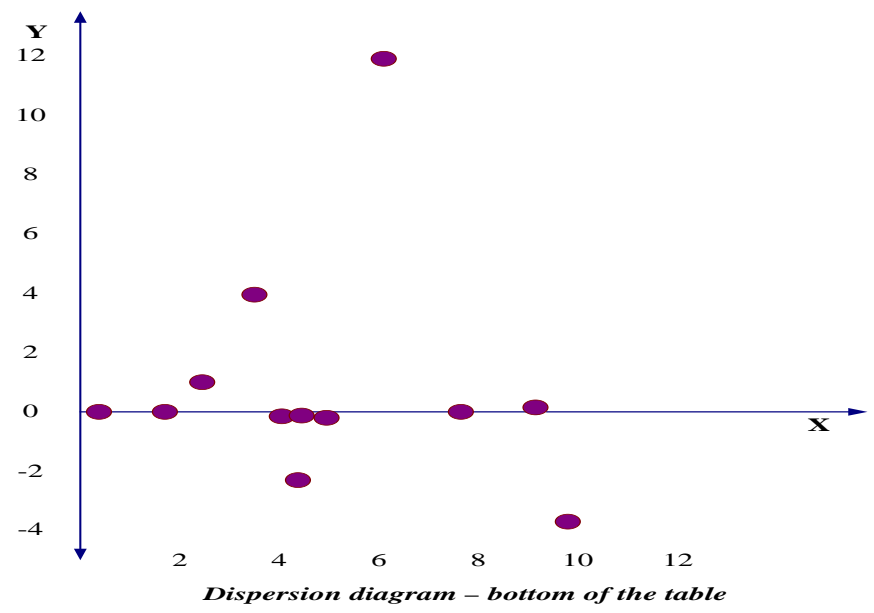

There is no significant correlation between investment and sports results at mid-table clubs and clubs at the bottom of the table. The graphic representation of the results of the DEA method can be seen in the figures 712. The results of the DEA method show that mid-table and lower down the league clubs are mainly on the efficiency frontier or close to the efficiency frontier compared to title holders, who are far from the efficiency frontier due to their financial results. Figures 7 and 8 show results for year 2011 in which the clubs Smederevo, Hajduk and Sloboda made the efficiency frontier, while Red Star was farthest from the efficiency frontier. Red Star also took the farthest position in 2010, as can be seen in figures 9 and 10. In 2009 only two clubs (Spartak and Javor) made the efficiency frontier.

It is important to keep in mind that the results of accounting periods of football clubs are often incomparable. To be precise, transfer revenue in some clubs can influence financial results significantly. The financial result of these clubs is subject to large fluctuations, namely it is determined dominantly by the period which is chosen for the sale of players. It is important to also remember that the result is greatly influenced by the current financial crisis. In Western Europe the crisis did not influence the decrease of revenue from the sale of first league football clubs, while decreases were recorded in Balkan countries (UEFA, 2013). Having in mind the depth and destructiveness of the crisis, the 
Mijatović $P$. et al.: Effect of investment on financial and sports results

above-mentioned is not surprising. For more details consult Ljumović (2009), Filipović (2010) and Stevanović et al. (2010).

Figure 7. DEA input method for year 2011

Figure 8. DEA output method for year 2011.
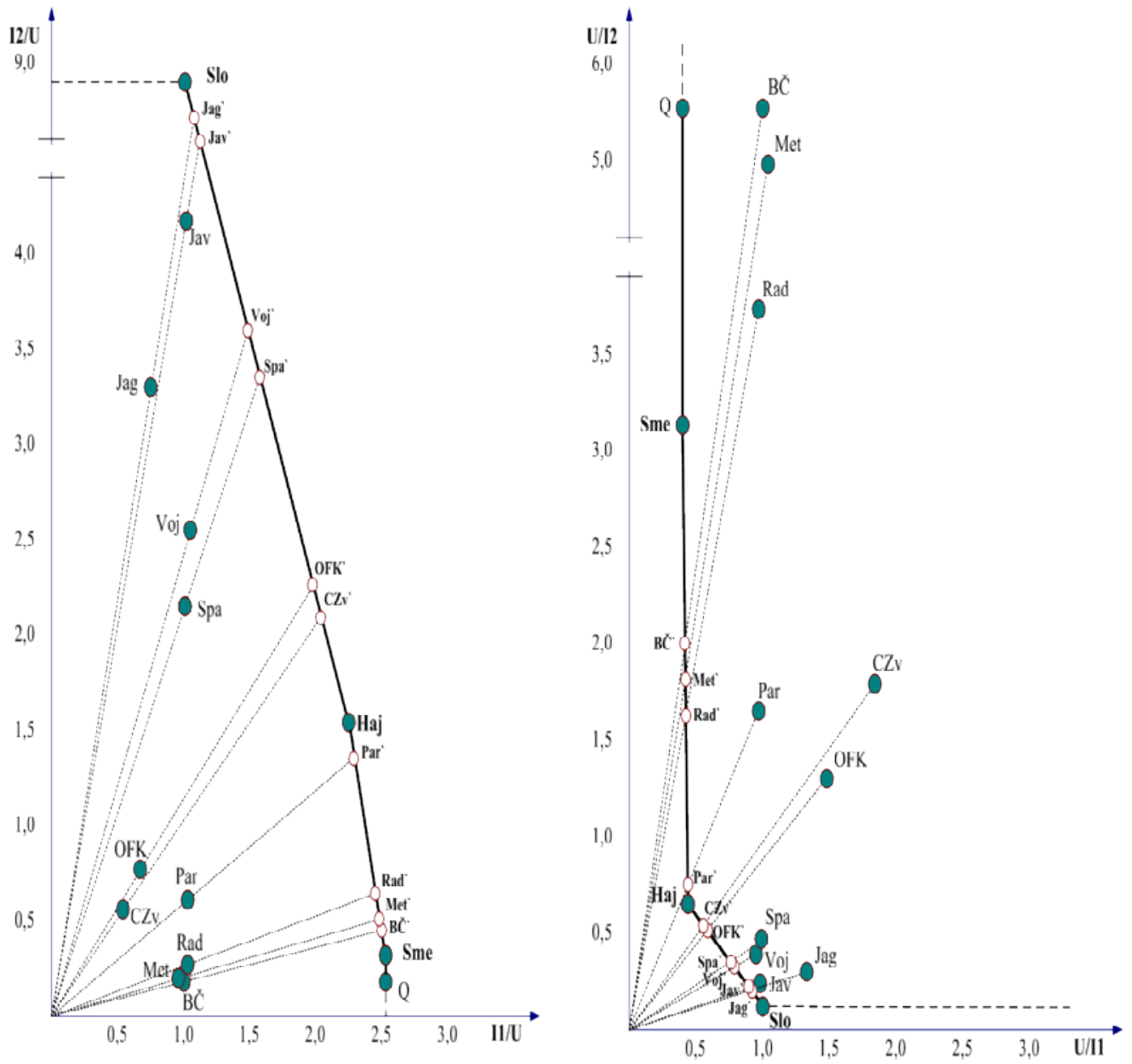
Mijatović $P$. et al.: Effect of investment on financial and sports results

Figure 9. DEA input method for year 2010

Figure 10. DEA output method for year 2010.
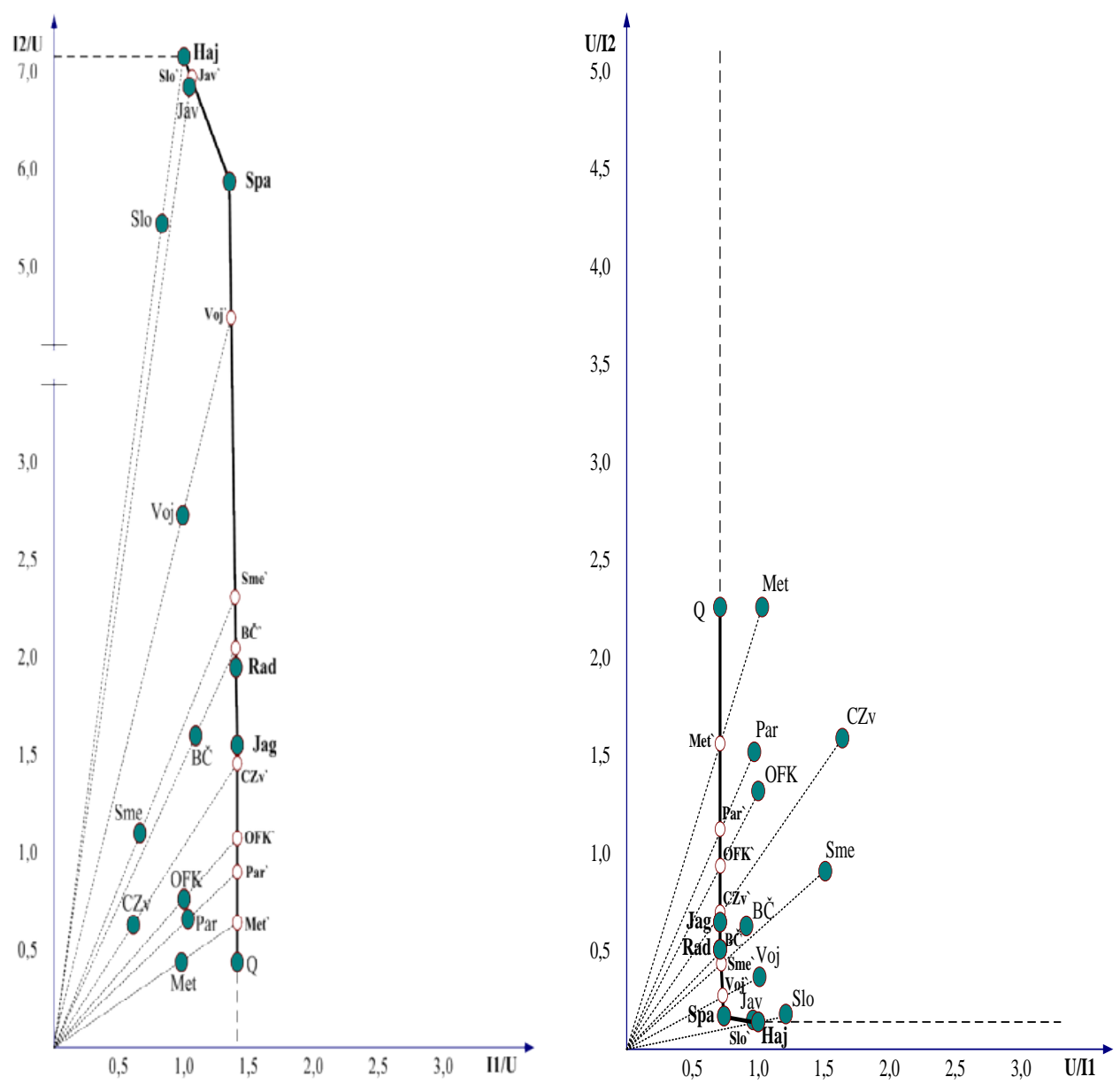
Mijatović $P$. et al.: Effect of investment on financial and sports results

Figure 11. DEA input method for year 2009.

Figure 12. DEA output method for year 2009.
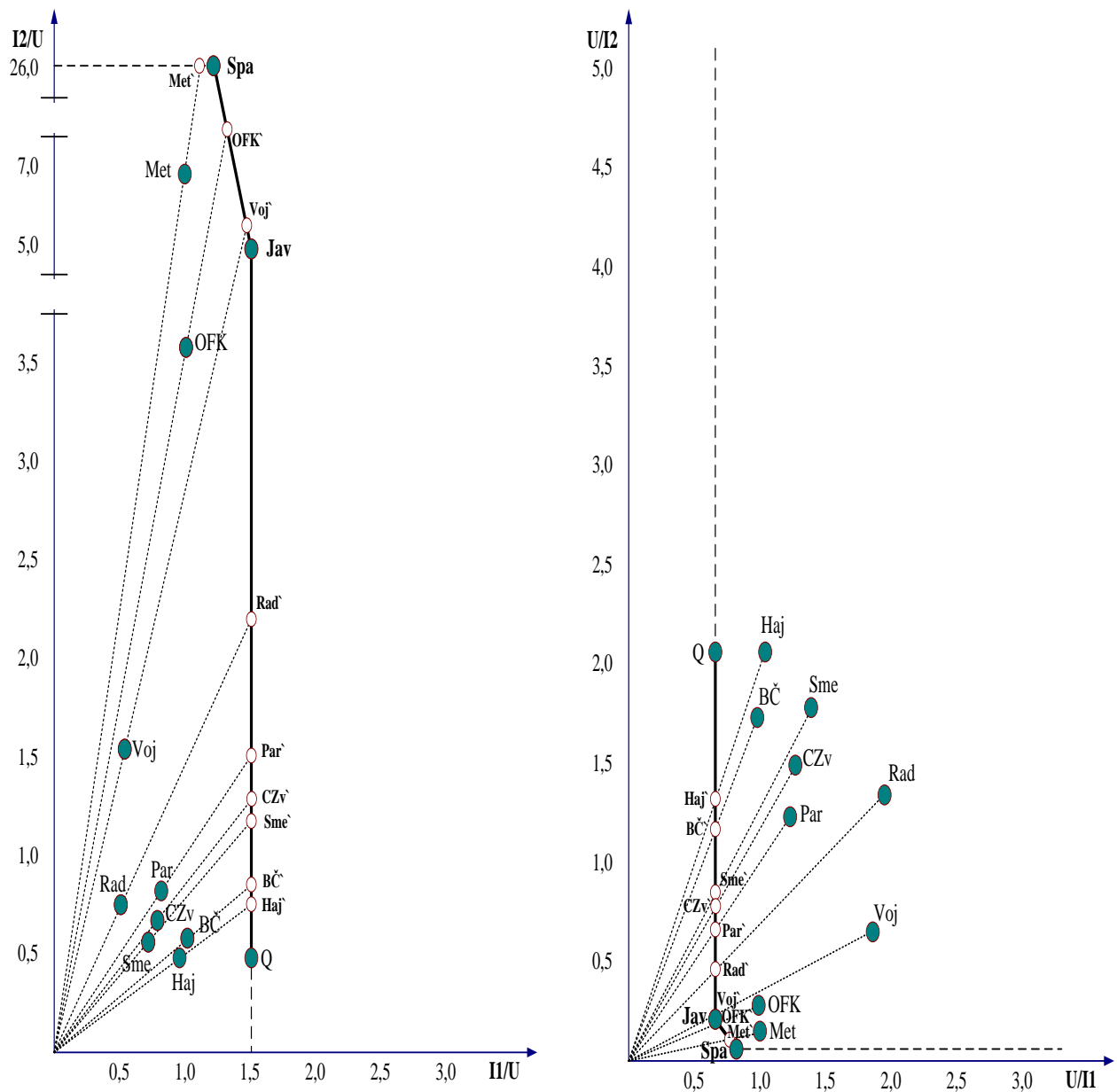

It is realistic to assume that the generally poor financial performance of Serbian football clubs are in addition deteriorating due to a greater certainty about which club is going to win the championship (Louis-Schmeling paradox). 
Mijatović P. et al.: Effect of investment on financial and sports results

Table 1.Total expenses, total revenue and values of overvalued position in the league.

\begin{tabular}{|c|c|c|c|c|}
\hline & & total expenses & total revenue & $\begin{array}{l}\text { Overvalued } \\
\text { position }\end{array}$ \\
\hline \multirow[t]{13}{*}{2011} & Partizan & 2.559 .940 .000 & 2.633 .242 .000 & 155.57 \\
\hline & CrvenaZvezda & 1.992 .547 .000 & 1.082 .070 .000 & 111.12 \\
\hline & Vojvodina & 310.765 .000 & 327.392 .000 & 79.37 \\
\hline & OFK Beograd & 191.559 .000 & 129.279 .000 & 14.76 \\
\hline & Rad & 280.728 .000 & 288.892 .000 & 7.53 \\
\hline & Spartak & 95.895 .000 & 96.663 .000 & 20.66 \\
\hline & Sloboda Point & 46.775 .000 & 47.051 .000 & 40.50 \\
\hline & Javor & 25.300 .000 & 25.814 .000 & 10.54 \\
\hline & Borac & 77.614 .000 & 77.738 .000 & 1.40 \\
\hline & Smederevo & 85.771 .000 & 217.065 .000 & 2.74 \\
\hline & Jagodina & 171.578 .000 & 128.675 .000 & 56.69 \\
\hline & Hajduk & 34.956 .000 & 78.608 .000 & 5.38 \\
\hline & Metalac & 49.593 .000 & 47.806 .000 & 1.00 \\
\hline \multirow[t]{13}{*}{2010} & Partizan & 2.363 .164 .000 & 2.444 .736 .000 & 155.57 \\
\hline & CrvenaZvezda & 1.763 .584 .000 & 1.072 .292 .000 & 111.12 \\
\hline & Vojvodina & 290.619 .000 & 286.551 .000 & 79.37 \\
\hline & OFK Beograd & 271.921 .000 & 272.459 .000 & 20.66 \\
\hline & $\operatorname{Rad}$ & 290.422 .000 & 406.882 .000 & 56.69 \\
\hline & Spartak & 68.844 .000 & 93.021 .000 & 40.50 \\
\hline & Sloboda Point & 53.138 .000 & 43.920 .000 & 28.93 \\
\hline & Javor & 21.569 .000 & 22.435 .000 & 14.76 \\
\hline & Borac & 66.075 .000 & 72.296 .000 & 10.54 \\
\hline & Smederevo & 68.532 .000 & 45.238 .000 & 7.53 \\
\hline & Jagodina & 24.817 .000 & 34.963 .000 & 3.84 \\
\hline & Hajduk & 3.722 .000 & 3.730 .000 & 2.74 \\
\hline & Metalac & 44.218 .000 & 43.127 .000 & 1.96 \\
\hline \multirow[t]{11}{*}{2009} & Partizan & 1.906 .623 .000 & 1.554 .579 .000 & 155.57 \\
\hline & CrvenaZvezda & 1.651 .654 .000 & 1.304 .686 .000 & 111.12 \\
\hline & Vojvodina & 263.506 .000 & 141.291 .000 & 40.50 \\
\hline & OFK Beograd & 221.186 .000 & 223.329 .000 & 79.37 \\
\hline & Rad & 197.184 .000 & 101.194 .000 & 14.76 \\
\hline & Spartak & 21.727 .000 & 26.452 .000 & 56.69 \\
\hline & Javor & 42.498 .000 & 64.146 .000 & 20.66 \\
\hline & Borac & 93.186 .000 & 95.053 .000 & 5.38 \\
\hline & Smederevo & 133.771 .000 & 96.516 .000 & 7.53 \\
\hline & Hajduk & 40.455 .000 & 38.833 .000 & 1.96 \\
\hline & Metalac & 15.482 .000 & 15.482 .000 & 10.54 \\
\hline
\end{tabular}

Source: author calculation

By using the data available on the web pages of the Serbian Business Registers Agency and Football Association of Serbia, calculations were made. Table 1 provides the total expenses, total revenue and values of the overvalued position in the League. The graphic display of the results and the determination of efficiency using this diagram involve the calculation of the input and the output ratio (Table 2). 
Mijatović P. et al.: Effect of investment on financial and sports results

Table 2. Inputs, outputs and ratio between inputs and outputs.

\begin{tabular}{|c|c|c|c|c|}
\hline & & total expenses & total revenue & $\begin{array}{l}\text { Overvalued } \\
\text { position }\end{array}$ \\
\hline \multirow[t]{13}{*}{2011} & Partizan & 2.559 .940 .000 & 2.633 .242 .000 & 155.57 \\
\hline & CrvenaZvezda & 1.992 .547 .000 & 1.082 .070 .000 & 111.12 \\
\hline & Vojvodina & 310.765 .000 & 327.392 .000 & 79.37 \\
\hline & OFK Beograd & 191.559 .000 & 129.279 .000 & 14.76 \\
\hline & Rad & 280.728 .000 & 288.892 .000 & 7.53 \\
\hline & Spartak & 95.895 .000 & 96.663 .000 & 20.66 \\
\hline & Sloboda Point & 46.775 .000 & 47.051 .000 & 40.50 \\
\hline & Javor & 25.300 .000 & 25.814 .000 & 10.54 \\
\hline & Borac & 77.614 .000 & 77.738 .000 & 1.40 \\
\hline & Smederevo & 85.771 .000 & 217.065 .000 & 2.74 \\
\hline & Jagodina & 171.578 .000 & 128.675 .000 & 56.69 \\
\hline & Hajduk & 34.956 .000 & 78.608 .000 & 5.38 \\
\hline & Metalac & 49.593 .000 & 47.806 .000 & 1.00 \\
\hline \multirow[t]{13}{*}{2010} & Partizan & 2.363 .164 .000 & 2.444 .736 .000 & 155.57 \\
\hline & CrvenaZvezda & 1.763 .584 .000 & 1.072 .292 .000 & 111.12 \\
\hline & Vojvodina & 290.619 .000 & 286.551 .000 & 79.37 \\
\hline & OFK Beograd & 271.921 .000 & 272.459 .000 & 20.66 \\
\hline & Rad & 290.422 .000 & 406.882 .000 & 56.69 \\
\hline & Spartak & 68.844 .000 & 93.021 .000 & 40.50 \\
\hline & Sloboda Point & 53.138 .000 & 43.920 .000 & 28.93 \\
\hline & Javor & 21.569 .000 & 22.435 .000 & 14.76 \\
\hline & Borac & 66.075 .000 & 72.296 .000 & 10.54 \\
\hline & Smederevo & 68.532 .000 & 45.238 .000 & 7.53 \\
\hline & Jagodina & 24.817 .000 & 34.963 .000 & 3.84 \\
\hline & Hajduk & 3.722 .000 & 3.730 .000 & 2.74 \\
\hline & Metalac & 44.218 .000 & 43.127 .000 & 1.96 \\
\hline \multirow[t]{11}{*}{2009} & Partizan & 1.906 .623 .000 & 1.554 .579 .000 & 155.57 \\
\hline & CrvenaZvezda & 1.651 .654 .000 & 1.304 .686 .000 & 111.12 \\
\hline & Vojvodina & 263.506 .000 & 141.291 .000 & 40.50 \\
\hline & OFK Beograd & 221.186 .000 & 223.329 .000 & 79.37 \\
\hline & $\mathrm{Rad}$ & 197.184 .000 & 101.194 .000 & 14.76 \\
\hline & Spartak & 21.727 .000 & 26.452 .000 & 56.69 \\
\hline & Javor & 42.498 .000 & 64.146 .000 & 20.66 \\
\hline & Borac & 93.186 .000 & 95.053 .000 & 5.38 \\
\hline & Smederevo & 133.771 .000 & 96.516 .000 & 7.53 \\
\hline & Hajduk & 40.455 .000 & 38.833 .000 & 1.96 \\
\hline & Metalac & 15.482 .000 & 15.482 .000 & 10.54 \\
\hline
\end{tabular}

Source: author calculation

Only two clubs (Javor and Spartak) of the eleven football clubs that were analysed in 2009 , created the envelope line of the efficiency frontier. Both clubs were positioned among four clubs with the lowest total expenditures for the given season. The DEA method showed that mid-table and relegation fodders are mainly on and close to the efficiency frontier in comparison with 
the hopefuls for the title, who are far from the efficiency frontier due to their financial results.

\section{Conclusions}

The professionalization of sport makes a sport score as an indicator of success irrelevant. The management of sports clubs is becoming more sophisticated, since the financial performance has become equally important, if not more important as a goal than sports achievement. If the aim of the football club is defined as maximisation of a club's value, the management becomes even more complex, since the financial and sports results also influence a club's value. In the past few years, many authors have researched the relation between sports and financial results. The majority of the authors emphasise that it is necessary to establish a synergy between sports and financial results, in order to consider football clubs being successful.

The research findings show a strong positive correlation between investment and sports results only for the higher ranked football clubs, while econometric regression output is minimal or nonexistent for smaller clubs. Furthermore, there is no correlation dependence between investment and net income of any football club. The results of the DEA method show that mid-table and relegation fodders are mainly on the efficiency frontier or close to the efficiency frontier compared to title holders, who are far from the efficiency frontier due to their financial results. The general conclusion of the research is that the majority of football clubs, especially the best ranked clubs with the highest expenditure, need to decrease expenditure since there is no alternative for increasing revenue.

\section{References}

Barajas, A. (2009). Analysing the technical efficiency of the Spanish Football League First Division with a Random Frontier Model. Applied Economics, 41(25): 32393247.

Barajas, A., Fernández-Jardón, C. \& Crolley, L. (2005). "Does sports performance influence revenues and economic results in Spanish Football?" MPRA Paper No. 3234. Hyperlink: [http://mpra.ub.uni-muenchen.de/3234/]. Retrieved on 4 July 2012.

Barros C.P., Assaf, A. \& Sá-Earp, F. (2010). Brazilian football league technical efficiency: A Simar and Wilson Approach. Journal of Sports Economics, 11(6): 641-651.

Barros, C.P. \& Leach, S. (2006). Analyzing the performance of the English F.A. Premier League with Econometric Frontier Model. Journal of Sports Economics, 7(4): 391-407. 
Mijatović P. et al.: Effect of investment on financial and sports results

Bosca, J.E., Liern, V., Martinez, A. \& Sala, R. (2009). Increasing offensive or defensive efficiency? An analysis of Italian and Spanish football. Omega, 37(1): 63-78.

Cvijanović, J., Bešić, C., Sajfert, Z., Grujčić, Z. \& Lazić, J. (2010). Application of the efficiency of nonprofit organizations. Technics Technologies Education Management (TTEM), 7(3): 575-589.

Cvijanović, J., Sajfert, Z., Grujčić, Z., Lazić, J. \& Bešić, C. (2012). Application of DEA method in comparative analysis of non-profit organizations efficiency. Technics Technologies Education Management (TTEM), 7(2): 724-746.

Espitia-Escuer, M. \& García-Cebrián, L. (2010). Measurement of the efficiency of football teams in the Champions League. Managerial and Decision Economics, 31(6): 373-386.

Filipović, S. (2010). Efekti globalne finansijske krize na finansijski sektor Srbije (trans.: The effects of global financial crisis on Serbian financial sector). Industrija, 38(3): 79-94.

Gette, C. (1996). "Numbers game: The accounting side of pro sports, business finance", Apr. 1, 1996. Hyperlink:

[http://businessfinancemag.com/hr/numbers-game-accounting-side-pro-sports]. Retrieved on 8 August 2012.

Haas, D.J., Kocher, M.G. \& Sutter, M. (2004). Measuring efficiency of German football teams by data envelopment analysis. Central European Journal of Operations Research and Economics, 12: 251-268.

Jardin, M. (2009). Efficiency of French football clubs and its dynamics. Munich Personal RePEc Archive Paper No. 19828, posted 8 January 2010 18:05 UTC. Hyperlink: [http://mpra.ub.uni-muenchen.de/19828/]. Retrieved on 16 July 2012.

Lee, Y.H. (2009). Evaluating management efficiency of Korean professional teams using Data Envelopment Analysis (DEA). International Journal of Applied Sports Sciences, 21(2): 93-112.

Ljumović, I. (2009): Prelazak rizika u neizvesnost u uslovima globalne krize (trans.: Moving risk to uncertainty in the global crisis). Zbornik Matice srpske za društvene nauke, 129: 61-72.

Morrow, S. (1999). The new business of football: Accountability and finance in football. London: Macmillan Business.

Pavlović, V., Ljumović, I. \& Knežević, G. (2014). Specifičnosti vrednovanja ljudskih resursa u fudbalskoj industriji (trans.: The specifics of the evaluation of human resources in the football industry). Poslovna ekonomija, 8(2): 223-238.

Pavlović, V., Mijatović, P. \& Milačić, S. (2013). Financial reporting of football clubs in Serbia. Journal for Theory and Practice Management, 18(67): 55-62.

Pavlović, V., Milačić, S. \& Ljumović, I. (2014). Controversies about accounting treatment of transfer fee in football industry. Journal for Theory and Practice Management, 19(70): 17-24.

[Picazo-Tadeo, A. \& González-Gómez, F. (2010). Does playing several competitions influence a team's league performance? Evidence from Spanish professional football. Central European Journal of Operations Research, 18: 413-432.

Pinnuck, M. \& Potter, B. (2004). "The financial performance of AFL football clubs". School working papers, Series 2004, SWP 2004/15, Deakin University, Faculty of Business and Law, School of Accounting, Economics and Finance. Hyperlink:

[http://www.deakin.edu.au/buslaw/aef/workingpapers/papers/swp2004_15.pdf]. Retrieved on 15 July 2012. 
Mijatović P. et al.: Effect of investment on financial and sports results

Radovanović, S., Radojičić, M., Jeremić, V. \& Savić, G. (2013). A novel approach in evaluating efficiency of basketball players. Journal for Theory and Practice Management, 18(67): 37-45.

Rogge, N., Reeth, D.V. \& Puyenbroeck, T.V. (2013). Performance evaluation of Tour de France cycling teams using Data Envelopment Analysis. International Journal of Sport Finance, 8(3): 236-257.

Samagaio, A., Couto, E. \& Caiado, J. (2009). "Sporting, financial and stock market performance in English football: An empirical analysis of structural relationships", CEMAPRE Working Papers. Hyperlink: [http://ideas.repec.org/p/cma/wpaper/0906.html]. Retrieved on 25 July 2012.

Soleimani-Damaneh, J., Hamidi, M. \& Sajadi, N. (2011). Evaluating the performance of Iranian football teams utilizing linear programming. American Journal of Operations Research, 1: 65-72.

Stevanović, S., Đorović, M. \& Milanović, M. (2010). Svetska finansijska kriza i njene posledice na privredu Srbije (trans.: The global financial crisis and its impact on Serbian economy). Ekonomika poljoprivrede, 57(3): 353-368.

Szymanski, S. \& Smith, R. (1997). The English football industry: Profit, performance and industrial structure. International Review of Applied Economics, 11(1): 135153.

UEFA (2012). Club licensing and financial fair play regulations, Edition 2012. London (UK): UEFA.

UEFA (2013). Rapport de benchmarking sur la procédure d'octroi de licence aux clubs, exercise 2011, 04 février 2013 (trans.: Report on the benchmarking procedures for granting licences to clubs for the 2011 financial year). London (UK): UEFA.

Vrooman, J. (2007). Economics of sport. Scottish Journal of Political Economy, 54(3): 309-313. 